\title{
Simultaneous Recovery of Zinc and Manganese from Cadmium-Containing Mixed- Battery Leachate by Separation and Purification Process
}

\author{
Dong Ju Shin ${ }^{1,2}$, Sung-Ho Joo ${ }^{1}$, Dongseok Lee ${ }^{3}$, Jin-Tae Park ${ }^{1}$, Dong Joon Min ${ }^{2}$ and \\ Shun Myung Shin ${ }^{1,3, *}$ \\ ${ }^{1}$ Resources Recovery Research Center, Korea Institute of Geoscience and Mineral Resources, Daejeon, 34132, Republic of Korea \\ ${ }^{2}$ Department of Materials Science and Engineering, Yonsei University, Seoul, 03722, Republic of Korea \\ ${ }^{3}$ Resource Recycling Department, Korea University of Science \& Technology, Daejeon, 34113, Republic of Korea
}

\begin{abstract}
A study on the simultaneous separation of $\mathrm{Zn}$ and $\mathrm{Mn}$ from a feed solution containing various types of dissolved battery wastes was carried out by a solvent extraction process using D2EHPA. The selective recovery of $\mathrm{Zn}$ and $\mathrm{Mn}$ from feed solutions containing Cd ions is difficult due to their similar physicochemical behavior. Therefore, $99.9 \%$ of $\mathrm{Zn}, 99.8 \%$ of $\mathrm{Mn}$, and $99.9 \%$ of Cd were extracted using the optimum conditions of 40 vol\% D2EHPA, 40 vol\% NaOH concentration, 2-stage countercurrent extraction, and an O/A ratio of 2. The Co-extracted Co could be scrubbed using pH 2 sulfuric acid at an $\mathrm{O} / \mathrm{A}$ ratio of 1 , and $\mathrm{Cd}$ was then scrubbed using $0.5 \mathrm{M} \mathrm{Na}_{2} \mathrm{~S}_{2} \mathrm{O}_{3}$. The results of the Cd scrubbing experiments indicated that the optimum conditions were 3 -stage countercurrent scrubbing and an $\mathrm{O} / \mathrm{A}$ ratio of 2 , and the scrubbing efficiency of $\mathrm{Cd}$ was approximately $99.9 \%$. The $\mathrm{Zn}$ and $\mathrm{Mn}$ that remained in the loaded organic could be enriched by increasing the O/A ratio of the stripping stage to 6 . From this concentrated solution, high purity zinc manganese sulfate powder, which can be used as a raw material for fertilizer for crop cultivation, was manufactured. [doi:10.2320/matertrans.M2019033]
\end{abstract}

(Received January 29, 2019; Accepted March 12, 2019; Published April 19, 2019)

Keywords: hydrometallurgy, recycling of mixed battery wastes, cadmium, simultaneous zinc and manganese recovery, zinc manganese sulfate

\section{Introduction}

As the use of various electronic devices increases in the modern era, the demand for batteries, which are essential for the operation of such electronic devices, is also rapidly increasing. The increase in battery usage has spontaneously led to an increase in the generation of battery waste. In South Korea, 11,630 thousand tons of manganese/alkaline batteries, 483 thousand tons of nickel-cadmium batteries (Ni-Cd batteries), 195 thousand tons of nickel metal hydride batteries (NiMH batteries), and 300 thousand tons of lithium primary batteries were collected as waste in 2017. ${ }^{1)}$ These battery wastes still contain valuable metals such as $\mathrm{Zn}, \mathrm{Mn}$, $\mathrm{Co}, \mathrm{Ni}$, and $\mathrm{Li}$, and these elements can be recovered and used to synthesize various compounds for many types of industry. In particular, zinc manganese sulfate can be manufactured from $\mathrm{Zn}$ and $\mathrm{Mn}$ recovered from various resources, including battery wastes. This compound is used as a fertilizer for the cultivation of various crops such as fruits and grains. ${ }^{2,3)}$ However, battery wastes contain a typical heavy metal, Cd, in addition to the other valuable metals. If battery wastes are buried or incinerated without significant metallurgical processing, the $\mathrm{Cd}$ in the waste may cause air, soil, and water pollution. In addition, the $\mathrm{Cd}$ content of zinc manganese sulfate fertilizer must be controlled, because $\mathrm{Cd}$ adversely affects the cultivation of crops. Therefore, $\mathrm{Cd}$ should be removed during the metallurgical processing of battery wastes. Several studies have been conducted on the recovery of $\mathrm{Zn}$, Mn, and $\mathrm{Cd}$ from various battery wastes.

De Michelis et al. recovered $\mathrm{Zn}$ and $\mathrm{Mn}$ from spent alkaline and zinc-carbon batteries by leaching. $\mathrm{Zn}$ and $\mathrm{Mn}$ were $99 \%$ and $96 \%$ dissolved through a countercurrent leaching process, respectively. ${ }^{4)}$ De Souza and Tenorio recovered $\mathrm{Zn}$ and $\mathrm{Mn}$ simultaneously from household

*Corresponding author, E-mail: shin1016@kigam.re.kr alkaline batteries using a hydrometallurgical process consisting of leaching and electrowinning. However, the leaching efficiency of Mn was quite low at $40 \%$. 5) Salgado et al. tried to recover $\mathrm{Zn}$ and $\mathrm{Mn}$ from spent alkaline batteries by solvent extraction with Cyanex 272. 90\% of the $\mathrm{Zn}$ was extracted, whereas only $7 \%$ of the $\mathrm{Mn}$ was extracted. ${ }^{6)}$ Shin et al. studied the recovery of $\mathrm{Zn}$ and $\mathrm{Mn}$ from alkaline manganese batteries. Most of the $\mathrm{Zn}$ and Mn were leached using sulfuric acid in the presence of the reducing agent $\mathrm{H}_{2} \mathrm{O}_{2} \cdot{ }^{7)}$ Chen et al. recovered $\mathrm{Zn}$ and $\mathrm{Mn}$ from spent $\mathrm{Zn}-\mathrm{MnO}_{2}$ battery electrode powder. The electrode powder was treated by reductive sulfuric acid leaching, and then $\mathrm{Zn}(\mathrm{OH})_{2}$ and $\mathrm{Mn}(\mathrm{OH})_{2}$ were precipitated by increasing the $\mathrm{pH}$ using $\mathrm{NaOH}$. These hydroxides were calcined and converted into their oxide forms. The recovery efficiencies of $\mathrm{Zn}$ and $\mathrm{Mn}$ were $91 \%$ and $94 \%$, respectively. ${ }^{8)}$ Zhu et al. recovered $\mathrm{Cd}$ by vacuum distillation at the high temperature of $1173 \mathrm{~K}$ over 3 hours at $10 \mathrm{~Pa}$, and Umesh and Hong recovered $88 \%$ of $\mathrm{Ni}$ and $84 \%$ of $\mathrm{Cd}$ from $\mathrm{Ni}-\mathrm{Cd}$ battery wastes by a chemical method using ferric sulfate solution. ${ }^{9,10)}$ Mahandra et al. studied the recovery of $\mathrm{Zn}$ and $\mathrm{Cd}$ from $\mathrm{Zn}-\mathrm{C}$ batteries and $\mathrm{Ni}-\mathrm{Cd}$ batteries, respectively. However, each metal was recovered separately without mixing the two types batteries by solvent extraction using Cyphos IL 104. ${ }^{11)}$ The BATENUS process is used for the recovery of metals from mixtures of zinc-carbon, alkaline manganese, lithium, and $\mathrm{Ni}-\mathrm{Cd}$ cells. This process consists of mechanical treatment and hydrometallurgical processing, finally recovering $\mathrm{Zn}, \mathrm{Cu}, \mathrm{Ni}, \mathrm{Cd}$, and $\mathrm{Mn}$. However, this process was discontinued because it was not economical. ${ }^{12)}$ Tanong et al. studied the recovery of $\mathrm{Zn}, \mathrm{Mn}$, $\mathrm{Cd}, \mathrm{Co}$, and $\mathrm{Ni}$ from spent mixed batteries by sequential hydrometallurgical processing. After applying a leaching process to the spent mixed battery powder, $\mathrm{Zn}$ was first extracted using Cyanex 272 and TBP. Mn and Cd were then simultaneously extracted using D2EPHA and TBP. After stripping $\mathrm{Mn}$ and $\mathrm{Cd}$ from the loaded organic, $\mathrm{Cd}$ was 
recovered as a metal by electrodeposition, and $\mathrm{Mn}$ was precipitated as $\mathrm{MnCO}_{3}{ }^{13,14)}$

In addition, various studies have been carried out to separate and recover $\mathrm{Zn}$, Mn, and Cd from sources other than battery wastes. Kumbasar studied the recovery of $\mathrm{Cd}$ from a zinc plant leaching solution by an emulsion liquid membrane using trioctylamine (TOA). The recovery of $\mathrm{Cd}$ reached $95 \%$ under the optimum conditions, but about $1.4 \%$ of the $\mathrm{Zn}$ was also extracted. ${ }^{15)}$ Gupta et al. extracted Cd using Cyanex 923 from a hydrochloric acid medium also containing $\mathrm{Al}$, $\mathrm{Fe}, \mathrm{In}, \mathrm{Mn}, \mathrm{Co} \mathrm{Ni}, \mathrm{Cu}, \mathrm{Zn}$, and $\mathrm{Pb}$. Selective recovery of more than $98 \%$ of $\mathrm{Cd}$ was achieved. ${ }^{16)}$ Haghighi et al. studied the separation of $\mathrm{Zn}$ from $\mathrm{Mn}, \mathrm{Mg}, \mathrm{Ca}$, and $\mathrm{Cd}$ using D2EHPA. The optimum conditions were 3-stage countercurrent extraction and an $\mathrm{O} / \mathrm{A}$ ratio of 1 , and the extraction efficiency of $\mathrm{Zn}$ was $89 \%$. By scrubbing using a $\mathrm{ZnSO}_{4}$ solution, the trace concentrations of $\mathrm{Fe}, \mathrm{Mn}, \mathrm{Ca}$, and $\mathrm{Cd}$ in the loaded organic were rejected, and finally an $88.8 \mathrm{~g} / \mathrm{L} \mathrm{Zn}$ solution was obtained. ${ }^{17)}$ Daryabor et al. studied the solvent extraction of $\mathrm{Cd}$ and $\mathrm{Zn}$ from sulfate solutions using D2EHPA by comparing mechanical agitation and ultrasonic irradiation. In the presence of only the ultrasound system, both the $\mathrm{Cd}$ and $\mathrm{Zn}$ extraction efficiencies increased, so its selectivity was lower than that of the mechanical stirring system. Using both the mechanical and ultrasonic systems, on the other hand, $\mathrm{Zn}$ was extracted selectively from $\mathrm{Cd}$ by D2EHPA. ${ }^{18)}$

Until now, most studies have focused on the recovery of valuable metals from a single type of battery waste, which is a way to minimize the effects of other impurities on the recovery of the desired elements. In addition, research has yet to be conducted on the possibility of applying products obtained through such recycling processes to other types of industry. In this study, therefore, zinc manganese sulfate, which is a raw material for fertilizer applied in other industries, i.e., agriculture, was produced by simultaneously recovering $\mathrm{Zn}$ and $\mathrm{Mn}$ from the mixed battery wastes. Moreover, the $\mathrm{Cd}$ in the mixed battery wastes, which has an adverse effect on zinc manganese sulfate, was separated from $\mathrm{Zn}$ and Mn through a hydrometallurgical process.

\section{Experimental Procedure}

\subsection{The preparation of feed solution for solvent extraction}

The feed solution for the co-extraction of $\mathrm{Zn}$ and Mn was prepared by leaching with $1 \mathrm{M}$ sulfuric acid at the optimum conditions after heat treatment of the mixed batteries at a certain ratio as in the previous study. ${ }^{19)}$ Figure 1 shows the distinctions between the previous study and the present study as a process flow sheet. In the leaching solution, impurities such as $\mathrm{Fe}, \mathrm{Al}$, and $\mathrm{Cu}$ were precipitated by adding $\mathrm{NaOH}$ to raise the $\mathrm{pH}$. The elemental contents of the feed solution used for solvent extraction are shown in Table 1.

\subsection{Solvent extraction}

The extractant used for solvent extraction was di-2ethylhexyl phosphoric acid (D2EHPA), which is well-known as a representative cationic extractant. First, a $\mathrm{pH}$ isotherm experiment was carried out to derive the $\mathrm{pH}$ range in which

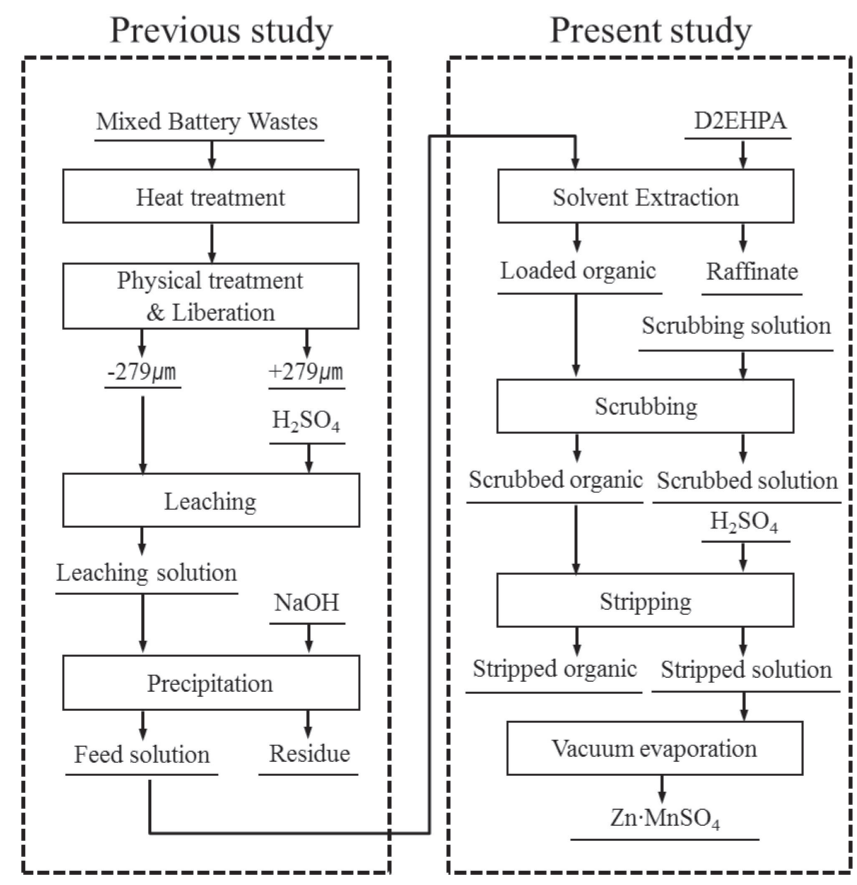

Fig. 1 Process flow sheets of previous (left) and present (right) study.

Table 1 Concentrations of elements and $\mathrm{pH}$ of feed solution for solvent extraction $(\mathrm{mg} / \mathrm{L})$

\begin{tabular}{ll}
\hline Component in feed solution & Concentration \\
\hline $\mathrm{Zn}$ & 9261 \\
$\mathrm{Mn}$ & 11242 \\
$\mathrm{Cd}$ & 2238 \\
$\mathrm{Co}$ & 10081 \\
$\mathrm{Ni}$ & 9175 \\
$\mathrm{Li}$ & 1714 \\
$\mathrm{Fe}$ & 1 \\
$\mathrm{Al}$ & 18 \\
$\mathrm{Cu}$ & 2 \\
$\mathrm{pH}$ & 5.56 \\
\hline
\end{tabular}

$\mathrm{Zn}$ and $\mathrm{Mn}$ can be simultaneously extracted. In the $\mathrm{pH}$ isotherm experiment, $40 \mathrm{vol} \%$ D2EHPA and the feed solution were added to a beaker at an $\mathrm{O} / \mathrm{A}$ ratio of 1 and stirred at $250 \mathrm{rpm}$ with a magnetic stir bar. The $\mathrm{pH}$ was increased from 1.5 to 8.0 at intervals of 0.5 with $\mathrm{NaOH}$ and sampled at equal intervals. After sampling, the raffinate was analyzed to determine the metal ion extraction efficiency. The D2EHPA was diluted with kerosene and its concentration was fixed at $40 \mathrm{vol} \%$ without purification. The extraction tendency of the metal was investigated using concentration of $\mathrm{NaOH}$ from $0 \mathrm{vol} \%$ to $50 \mathrm{vol} \%$, and the optimum concentration of $\mathrm{NaOH}$ was determined by calculating the distribution ratio and separation factor. A McCabe Thiele diagram for the countercurrent multi-stage extraction under the optimum conditions was constructed after the experiment according to the $\mathrm{O} / \mathrm{A}$ ratio. 


\subsection{Scrubbing and stripping experiment}

The optimization of the scrubbing process to remove the co-extracted impurities, especially $\mathrm{Co}$ and $\mathrm{Cd}$, was carried out using pH-adjusted sulfuric acid, ethylenediaminetetraacetic acid (EDTA), and sodium thiosulfate $\left(\mathrm{Na}_{2} \mathrm{~S}_{2} \mathrm{O}_{3}\right)$. The

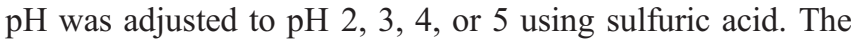
concentrations of EDTA and $\mathrm{Na}_{2} \mathrm{~S}_{2} \mathrm{O}_{3}$ used were $0.01,0.05$, $0.1,0.5$, and $1.0 \mathrm{M}$ for EDTA and $0.1,0.3,0.5,0.7$, and $1.0 \mathrm{M}$ for $\mathrm{Na}_{2} \mathrm{~S}_{2} \mathrm{O}_{3}$. The $\mathrm{O} / \mathrm{A}$ ratio of all the scrubbing experiments was 1. A countercurrent multi-stage scrubbing experiment was conducted for the complete removal of $\mathrm{Cd}$ using a McCabe Thiele diagram scheme for Cd scrubbing. In order to enrich and strip all of $\mathrm{Zn}$ and $\mathrm{Mn}$ from the loaded organic, stripping was carried out using 2-stage countercurrent stripping at an $\mathrm{O} / \mathrm{A}$ ratio of 6 using $1.5 \mathrm{M}$ sulfuric acid. All separation and purification experiments were carried out on a batch scale, and the organic and aqueous phases were mixed at $250 \mathrm{rpm}$ using an automatic shaker (model SI-600R, Jeiotech, South Korea). After the reaction, the organic and aqueous phases were separated in a separation funnel, and the aqueous phase was filtered and analyzed by atomic absorption spectroscopy (model AA-7000, Shimadzu Corp., Japan).

\subsection{Vacuum evaporation}

Vacuum evaporation was carried out by adding a zinc manganese sulfate solution to a $1 \mathrm{~L}$ round-bottom flask. The reaction was performed at $80 \mathrm{rpm}$ and $80^{\circ} \mathrm{C}$ using a mechanical stirrer (model R-215, BÜCHI, Switzerland) to remove the moisture as steam, and zinc manganese sulfate powder was obtained.

\section{Results and Discussions}

\section{1 pH isotherm experiment}

The purpose of the $\mathrm{pH}$ isotherm experiment was to identify the $\mathrm{pH}$ conditions in which the $\mathrm{Zn}$ and $\mathrm{Mn}$ in the feed solution could be simultaneously separated and purified and the impurities could be co-extracted. The results of $\mathrm{pH}$ isotherm experiment are shown in Fig. 2 and Table 2. The extraction of metal ions in the feed solution followed the order $\mathrm{Zn}>\mathrm{Mn}>\mathrm{Cd}>\mathrm{Co}>\mathrm{Ni}>\mathrm{Li}$. In particular, $\mathrm{Cd}$

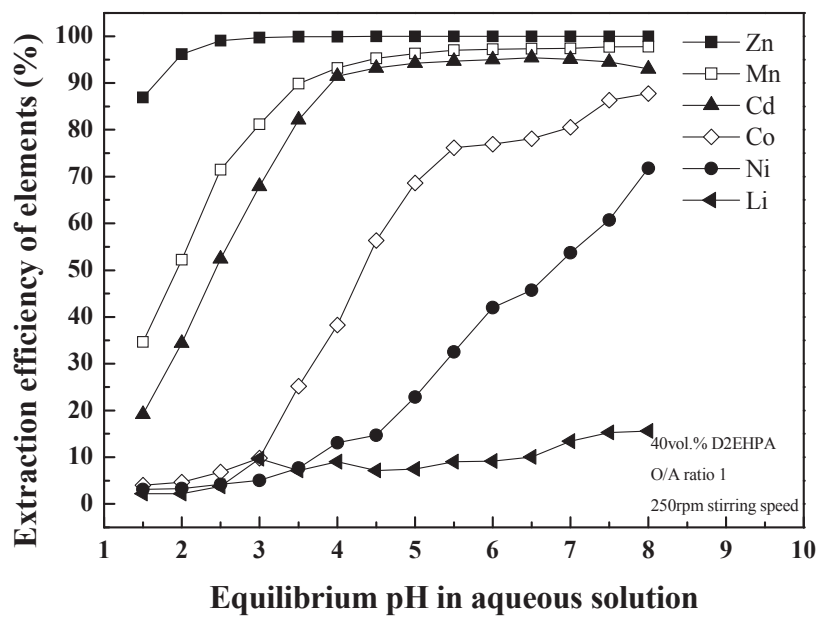

Fig. $2 \mathrm{pH}$ isotherm experiment for 40 vol\% D2EHPA.
Table 2 Concentrations of elements with equilibrium $\mathrm{pH}$ of the raffinate for solvent extraction $(\mathrm{mg} / \mathrm{L})$.

\begin{tabular}{|c|c|c|c|c|c|c|}
\hline \multirow{2}{*}{ Equilibrium pH } & \multicolumn{6}{|c|}{ Concentration of Elements ${ }^{*}$} \\
\hline & $\mathrm{Zn}$ & $\mathrm{Mn}$ & $\mathrm{Cd}$ & $\mathrm{Co}$ & $\mathrm{Ni}$ & $\mathrm{Li}$ \\
\hline 1.5 & 1213 & 7344 & 1809 & 9677 & 8891 & 1677 \\
\hline 2 & 352 & 5369 & 1468 & 9609 & 8874 & 1677 \\
\hline 2.5 & 83 & 3207 & 1065 & 9390 & 8787 & 1650 \\
\hline 3 & 28 & 2118 & 718 & 9090 & 8715 & 1548 \\
\hline 3.5 & 9 & 1141 & 399 & 7545 & 8471 & 1591 \\
\hline 4 & 9 & 760 & 191 & 6226 & 7974 & 1559 \\
\hline 4.5 & N.D & 534 & 152 & 4404 & 7824 & 1591 \\
\hline 5 & N.D & 414 & 129 & 3161 & 7075 & 1586 \\
\hline 5.5 & N.D & 337 & 119 & 2404 & 6189 & 1559 \\
\hline 6 & N.D & 317 & 111 & 2327 & 5322 & 1557 \\
\hline 6.5 & N.D & 298 & 103 & 2206 & 4982 & 1542 \\
\hline 7 & N.D & 293 & 110 & 1965 & 4247 & 1484 \\
\hline 7.5 & N.D & 256 & 122 & 1378 & 3605 & 1452 \\
\hline 8 & N.D & 247 & 156 & 1237 & 2587 & 1447 \\
\hline
\end{tabular}

${ }^{* 1}$ Not Detected

could be extracted as an impurity when extracting Mn. The $\Delta \mathrm{pH}_{50}$ value, which represents the difference in the $\mathrm{pH}$ value when $50 \%$ of the two metal ions are extracted, indicates the separation behavior of the two elements. If the value of $\Delta \mathrm{pH}_{50}$ is low, the extraction behavior of the two elements is similar, and separation of the two elements by solvent extraction will be difficult. Based on the $\mathrm{pH}$ isotherm experiment, the $\Delta \mathrm{pH}_{50}$ value between $\mathrm{Mn}$ and $\mathrm{Cd}$ is 0.5 . This means that $\mathrm{Cd}$ can be easily co-extracted in the $\mathrm{pH}$ range used to extract Mn. It also indicates that it is difficult to separate $\mathrm{Mn}$ from $\mathrm{Cd}$ by only the solvent extraction process. Therefore, from this solvent extraction process, conditions for the simultaneous extraction of $\mathrm{Zn}, \mathrm{Mn}$, and $\mathrm{Cd}$ were derived.

\subsection{Effect of $\mathrm{NaOH}$ concentration}

The equilibrium $\mathrm{pH}$ range of the aqueous solution in solvent extraction is an important factor in the separation and purification of metal ions. D2EHPA, which is an acidic extracting agent, exchanges hydrogen ions into aqueous solution when extracting metal ions, so that the $\mathrm{pH}$ of the aqueous solution is decreased after extraction. Eventually, the extraction of the metal ions no longer occurs since the concentration of hydrogen ions in the aqueous solution is increased. Therefore, it is necessary to adjust of $\mathrm{pH}$ value using $\mathrm{NaOH}$ to suppress the generation of hydrogen ions and to maintain a stable equilibrium $\mathrm{pH}$. In order to extract $\mathrm{Zn}, \mathrm{Mn}$, and Cd with D2EHPA, the effect of the adjusting the concentration of $\mathrm{NaOH}$ on the extraction efficiency of the metal was examined at 40 vol\% D2EHPA. The extraction efficiencies of $\mathrm{Zn}, \mathrm{Mn}$, and $\mathrm{Cd}$ increase with the concentration of $\mathrm{NaOH}$. The addition of $\mathrm{NaOH}$ prevented a significant drop in the $\mathrm{pH}$ during the solvent extraction process. 
Table 3 Distribution ratio $\left(\mathrm{D}_{(\mathrm{M})}\right)$ and separation factor values for $\beta_{((\mathrm{Zn}+\mathrm{Mn}+\mathrm{Cd}) / \mathrm{Co})}$ and $\mathrm{pH}$ at different concentration of $\mathrm{NaOH}(\mathrm{M}: \mathrm{Zn}$, $\mathrm{Mn}, \mathrm{Co}, \mathrm{Ni}, \mathrm{Cd})$.

\begin{tabular}{ccccccccc}
\hline \multirow{2}{*}{$\begin{array}{c}\text { Concentration } \\
\text { of } \mathrm{NaOH},\end{array}$} & \multicolumn{5}{c}{ Distribution ratio, $\mathrm{D}(\mathrm{M})$} & \multicolumn{3}{c}{ Separation } \\
\cline { 2 - 6 } vol.\% & $\mathrm{Zn}$ & $\mathrm{Mn}$ & $\mathrm{Co}$ & $\mathrm{Ni}$ & $\mathrm{Cd}$ & factor, & $\mathrm{pH}$ \\
\hline 0 & 5.43 & 0.38 & 5.63 & 0.00 & 1.32 & 103 & 1.27 \\
10 & 12.2 & 0.63 & 3.88 & 2.58 & 4.19 & 332 & 1.54 \\
20 & 35.8 & 1.17 & 8.26 & 4.77 & 31.5 & 451 & 1.81 \\
25 & 60.7 & 1.58 & 7.65 & 5.90 & 53.8 & 821 & 2.04 \\
30 & 114 & 2.40 & 9.54 & 8.15 & 85.4 & 1229 & 2.26 \\
40 & 499 & 4.91 & 17.6 & 9.46 & 228 & 2876 & 2.86 \\
50 & 999 & 11.0 & 41.3 & 11.8 & 583 & 2460 & 3.41 \\
\hline
\end{tabular}

On the other hand, $\mathrm{Co}$ and $\mathrm{Ni}$ were hardly extracted because the equilibrium $\mathrm{pH}$ was maintained at about 3.4 even when the concentration of $\mathrm{NaOH}$ was $50 \mathrm{vol} \%$. Since some Co was extracted, however, the separation factor of $\mathrm{Co}$ with respect to $\mathrm{Zn}, \mathrm{Mn}$, and $\mathrm{Cd}$ for different concentration of $\mathrm{NaOH}$ should be considered to derive the optimum conditions. The separation factor can be derived from the distribution ratio, which represents the ratio of the concentrations present in the organic phase and aqueous phase. The distribution ratio and separation factor of $\mathrm{Co}$ with regards to $\mathrm{Zn}, \mathrm{Mn}$, and $\mathrm{Cd}$ was calculated as follows:

$$
\begin{aligned}
\mathrm{D}_{\mathrm{M}} & =\frac{[\mathrm{M}]_{\text {org }}}{[\mathrm{M}]_{\mathrm{aq}}} \\
\beta_{(\mathrm{Zn}+\mathrm{Mn}+\mathrm{Cd}) / \mathrm{Co})} & =\frac{\mathrm{D}_{\mathrm{Zn}}+\mathrm{D}_{\mathrm{Mn}}+\mathrm{D}_{\mathrm{Cd}}}{\mathrm{D}_{\mathrm{Co}}}
\end{aligned}
$$

Table 3 lists the distribution ratios (D) of the elements for each concentration of $\mathrm{NaOH}$ and the separation factor of $\mathrm{Co}$ compared with those of $\mathrm{Zn}, \mathrm{Mn}$, and $\mathrm{Cd}$. The value of the separation factor was the highest $(2,876)$ at $40 \mathrm{vol} \% \mathrm{NaOH}$ concentration. Although more $\mathrm{Zn}$ and $\mathrm{Mn}$ were extracted at $50 \mathrm{vol} \% \mathrm{NaOH}$ concentration, the relative co-extraction of Co was also greater. This means that the separation of Co from $\mathrm{Zn}, \mathrm{Mn}$, and $\mathrm{Cd}$ is more difficult at $50 \mathrm{vol} \% \mathrm{NaOH}$ concentration. Therefore, the separation factor at $40 \mathrm{vol} \%$ $\mathrm{NaOH}$ concentration was lower than that at $50 \mathrm{vol} \% \mathrm{NaOH}$ concentration. As a result, the optimum concentration of $\mathrm{NaOH}$ for the solvent extraction of $\mathrm{Zn}, \mathrm{Mn}$, and $\mathrm{Cd}$ was 40 vol\%.

\subsection{McCabe Thiele diagram for the extraction of $\mathrm{Zn}$, Mn, and Cd}

In order to simultaneously extract $\mathrm{Zn}, \mathrm{Mn}$, and $\mathrm{Cd}$, a $40 \mathrm{vol} \%$ of concentration of $\mathrm{NaOH}$ and a $40 \mathrm{vol} \%$ D2EHPA concentration were set as the optimal conditions. However, since not all of the $\mathrm{Zn}, \mathrm{Mn}$, and $\mathrm{Cd}$ in the feed solution could be extracted in a single stage under these conditions, adjustment of the $\mathrm{O} / \mathrm{A}$ ratio and countercurrent multi-stage extraction should be considered. As the extraction proceeds in the countercurrent direction, the extraction efficiency of the desired metal can be improved through the crowding

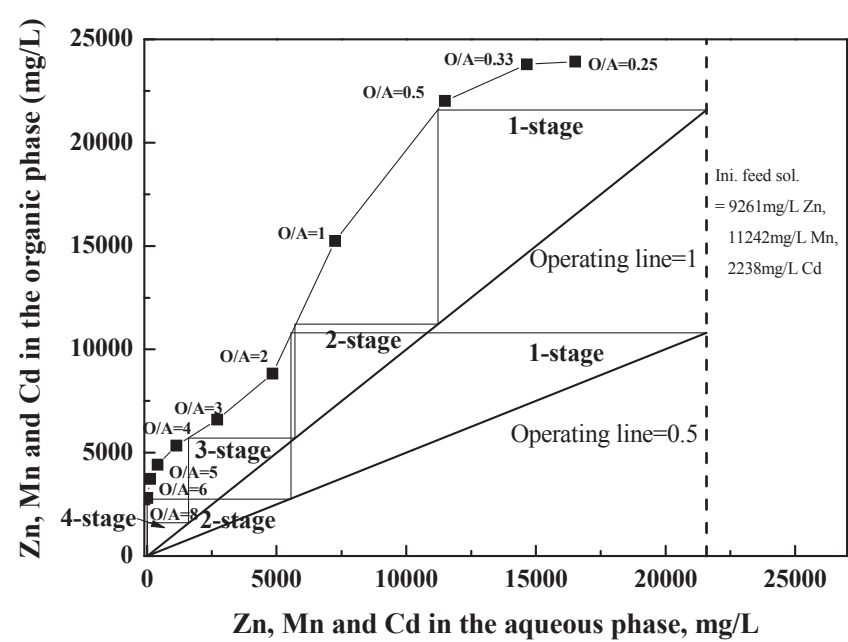

Fig. 3 McCabe Thiele diagram for the extraction of zinc, manganese and cadmium.

Table 4 The concentrations of the elements in the loaded organic and raffinate and their extraction efficiency after 2-stage counter-current extraction $(\mathrm{O} / \mathrm{A}$ ratio $=2)$.

\begin{tabular}{ccccc}
\hline Element & $\begin{array}{c}\text { Feed } \\
\text { solution, } \\
\mathrm{mg} / \mathrm{L}\end{array}$ & $\begin{array}{c}\text { Raffinate, } \\
\mathrm{mg} / \mathrm{L}\end{array}$ & $\begin{array}{c}\text { Loaded } \\
\text { organic, } \\
\mathrm{mg} / \mathrm{L}\end{array}$ & $\begin{array}{c}\text { Extraction } \\
\text { efficiency, \% }\end{array}$ \\
\hline $\mathrm{Zn}$ & 9261 & $\mathrm{~N} . \mathrm{D}$ & 4630 & 99.9 \\
$\mathrm{Mn}$ & 11242 & 18 & 5612 & 99.8 \\
$\mathrm{Co}$ & 10081 & 10070 & 5.5 & 0.1 \\
$\mathrm{Cd}$ & 2238 & N.D & 1118 & 99.9 \\
$\mathrm{Ni}$ & 9175 & 9177 & N.D & - \\
$\mathrm{Li}$ & 1714 & 1713 & N.D & - \\
\hline
\end{tabular}

effect. ${ }^{20)}$ The optimal $\mathrm{O} / \mathrm{A}$ ratio and number of stages can be determined from a McCabe Thiele diagram. Therefore, the McCabe Thiele diagram for $\mathrm{Zn}, \mathrm{Mn}$, and $\mathrm{Cd}$ was plotted and is shown in Fig. 3. According to the McCabe Thiele diagram, it is possible to extract the $\mathrm{Zn}, \mathrm{Mn}$, and $\mathrm{Cd}$ in the feed solution from a 4-stage countercurrent extraction process at operating line 1, i.e., $\mathrm{O} / \mathrm{A}=1$, and using 2 -stage countercurrent extraction at operating line 0.5 , i.e., $\mathrm{O} / \mathrm{A}=2$. When the operating line is increased, the usage of solvent is decreased, but the number of stages is increased. Lowering the operating line reduces the number of stages but increases the $\mathrm{O} / \mathrm{A}$ ratio and thus amount of solvent required. Also, when the $\mathrm{O} / \mathrm{A}$ ratio increases, the concentration of loaded metal ions is diluted. In this study, the solvent extraction of $\mathrm{Zn}, \mathrm{Mn}$, and $\mathrm{Cd}$ was carried out using 2-stage countercurrent extraction at an $\mathrm{O} / \mathrm{A}$ ratio of 2 , which increased the economic efficiency of the process by reducing the number of stages. The metal diluted by the increased O/A ratio of the extraction step can be re-concentrated by adjusting the O/A ratio in the stripping process. Table 4 shows the contents of the elements in the final raffinate and the extraction efficiency after 2-stage countercurrent solvent extraction. In the loaded organic, $\mathrm{Zn}, \mathrm{Mn}$, and $\mathrm{Cd}$ were present in concentrations of $4.6 \mathrm{~g} / \mathrm{L}, 5.6 \mathrm{~g} / \mathrm{L}$, and $1.1 \mathrm{~g} / \mathrm{L}$, respectively. The Co present 
Table 5 Concentrations of the elements in the loaded organic and in each scrubbing solution $(\mathrm{O} / \mathrm{A}$ ratio $=1)(\mathrm{mg} / \mathrm{L})$.

\begin{tabular}{|c|c|c|c|c|c|}
\hline \multirow{2}{*}{$\begin{array}{l}\text { Scrubbing } \\
\text { solution }\end{array}$} & Element & $\mathrm{Zn}$ & $\mathrm{Mn}$ & $\mathrm{Cd}$ & $\mathrm{Co}$ \\
\hline & $\begin{array}{l}\text { Loaded } \\
\text { organic }\end{array}$ & 4630 & 5612 & 1118 & 5.5 \\
\hline \multirow{4}{*}{$\mathrm{H}_{2} \mathrm{SO}_{4}$} & pH 2 & 4.02 & 10.0 & 8.08 & 5.48 \\
\hline & pH 3 & 0.38 & 5.73 & 3.49 & 4.59 \\
\hline & pH 4 & 0.26 & 2.41 & 0.53 & 0.28 \\
\hline & pH 5 & 0.25 & 2.32 & 0.51 & 0.22 \\
\hline \multirow{5}{*}{$\mathrm{EDTA}^{* 1}$} & $0.01 \mathrm{M}$ & 66.4 & 263 & 363 & - \\
\hline & $0.05 \mathrm{M}$ & 308 & 986 & 730 & - \\
\hline & $0.1 \mathrm{M}$ & 763 & 1394 & 829 & - \\
\hline & $0.5 \mathrm{M}$ & 4320 & 5029 & 833 & - \\
\hline & $1.0 \mathrm{M}$ & - & - & - & - \\
\hline \multirow{5}{*}{$\mathrm{Na}_{2} \mathrm{~S}_{2} \mathrm{O}_{3}{ }^{* 1}$} & $0.1 \mathrm{M}$ & N.D & N.D & 73.1 & - \\
\hline & $0.3 \mathrm{M}$ & N.D & N.D & 939 & - \\
\hline & $0.5 \mathrm{M}$ & N.D & N.D & 1045 & - \\
\hline & $0.7 \mathrm{M}$ & N.D & N.D & 1100 & - \\
\hline & $1.0 \mathrm{M}$ & N.D & N.D & 1127 & - \\
\hline
\end{tabular}

${ }^{* 1}$ Performed after scrubbing Co using a pH-adjusted $\mathrm{H}_{2} \mathrm{SO}_{4}$ solution

could easily be scrubbed because its concentration in the loaded organic was very low at $5.5 \mathrm{mg} / \mathrm{L}$.

\subsection{Co and Cd scrubbing experiment}

In order to recover only $\mathrm{Zn}$ and $\mathrm{Mn}$ from the loaded organic solution containing $\mathrm{Zn}, \mathrm{Mn}, \mathrm{Co}$, and $\mathrm{Cd}$, Co and $\mathrm{Cd}$ must scrubbed. The scrubbing results are shown in Table 5. At first, scrubbing experiments were carried out using $\mathrm{pH}-$ controlled sulfuric acid. When the $\mathrm{pH}$-controlled sulfuric acid was used as the scrubbing solution, $\mathrm{Zn}, \mathrm{Mn}$, and $\mathrm{Cd}$ were scarcely scrubbed over the entire $\mathrm{pH}$ range tested, but the Co in the loaded organic was completely scrubbed by a sulfuric acid solution adjusted to $\mathrm{pH} 2$. The reaction and the Gibbs free energy of scrubbing the loaded metal ions at $25^{\circ} \mathrm{C}$ by the $\mathrm{pH}$ controlled sulfuric acid solution were calculated as follows using data from the HSC Chemistry database. ${ }^{21)}$

$$
\begin{aligned}
& \mathrm{Cd}^{2+}+\mathrm{H}_{2} \mathrm{SO}_{4} \Leftrightarrow \mathrm{CdSO}_{4}+2 \mathrm{H}^{+} \quad \Delta \mathrm{G}\left(25^{\circ} \mathrm{C}\right)=-55.2 \mathrm{~kJ} \\
& \mathrm{Zn}^{2+}+\mathrm{H}_{2} \mathrm{SO}_{4} \Leftrightarrow \mathrm{ZnSO}_{4}+2 \mathrm{H}^{+} \quad \Delta \mathrm{G}\left(25^{\circ} \mathrm{C}\right)=-31.6 \mathrm{~kJ} \\
& \mathrm{Mn}^{2+}+\mathrm{H}_{2} \mathrm{SO}_{4} \Leftrightarrow \mathrm{MnSO}_{4}+2 \mathrm{H}^{+} \Delta \mathrm{G}\left(25^{\circ} \mathrm{C}\right)=-39.3 \mathrm{~kJ} \\
& \mathrm{Co}^{2+}+\mathrm{H}_{2} \mathrm{SO}_{4} \Leftrightarrow \mathrm{CoSO}_{4}+2 \mathrm{H}^{+} \quad \Delta \mathrm{G}\left(25^{\circ} \mathrm{C}\right)=-38.0 \mathrm{~kJ}
\end{aligned}
$$

As shown in the above reactions, $\mathrm{Co}, \mathrm{Zn}, \mathrm{Mn}$, and $\mathrm{Cd}$ can all be scrubbed using sulfuric acid. Therefore, $\mathrm{Zn}, \mathrm{Cd}$, and $\mathrm{Mn}$ can be lost in the scrubbing reaction. Since the concentration of Co is relatively low, however, Co can be completely scrubbed without large losses of $\mathrm{Cd}, \mathrm{Mn}$, and $\mathrm{Zn}$. The scrubbing of Co was carried out using only a single stage, rather than a multi-stage scrubbing procedure, to prevent the losses of $\mathrm{Cd}, \mathrm{Mn}$, and $\mathrm{Zn}$ from increasing.

The scrubbing of Co from the loaded organic by $\mathrm{pH}$ adjusted sulfuric acid was followed by the $\mathrm{Cd}$ scrubbing process. EDTA solution and $\mathrm{Na}_{2} \mathrm{~S}_{2} \mathrm{O}_{3}$ solution were both used to scrub $\mathrm{Cd}$ in order to select the scrubbing solution that best minimized the losses of $\mathrm{Zn}$ and $\mathrm{Mn}$ and could completely scrub $\mathrm{Cd}$ from the loaded organic. In the case of EDTA, loss of $\mathrm{Zn}$ and $\mathrm{Mn}$ also occurred, making it unsuitable as a scrubbing solution. In general, EDTA is known as a chelating agent that forms a complex with ions such as $\mathrm{Cd}^{2+}, \mathrm{Mn}^{2+}$, and $\mathrm{Zn}^{2+}$, and these complexes can be stable in the scrubbed solution. ${ }^{22)}$ In the scrubbing experiment using 1.0 M EDTA, precipitation occurred during the experiment and the scrubbing efficiency could not be calculated. On the other hand, no loss of $\mathrm{Zn}$ and $\mathrm{Mn}$ was observed for $\mathrm{Na}_{2} \mathrm{~S}_{2} \mathrm{O}_{3}$; only $\mathrm{Cd}$ was scrubbed. $\mathrm{Na}_{2} \mathrm{~S}_{2} \mathrm{O}_{3}$ is known to be an excellent scrubbing solution for $\mathrm{Cd}^{23)}$ Like EDTA, $\mathrm{Na}_{2} \mathrm{~S}_{2} \mathrm{O}_{3}$ is a chelating agent that complexes with cations such as $\mathrm{Cd}$. In particular, $\mathrm{Na}_{2} \mathrm{~S}_{2} \mathrm{O}_{3}$ forms $\mathrm{Cu}^{2+}, \mathrm{Ag}^{+}$, and $\mathrm{Hg}^{2+}$ complexes in addition to $\mathrm{Cd}^{2+}$ complexes, and does not form complexes with $\mathrm{Zn}^{2+}$ and $\mathrm{Mn}^{2+}$ ions. ${ }^{24,25)}$ This is because the stability constants of $\mathrm{Zn}^{2+}$ and $\mathrm{Mn}^{2+}$ ions with $\mathrm{S}_{2} \mathrm{O}_{3}{ }^{2-}$ ions are smaller than that with $\mathrm{Cd}^{2+}$ ion. ${ }^{26,27)}$ The reaction of $\mathrm{Cd}^{2+}$ ions with $\mathrm{Na}_{2} \mathrm{~S}_{2} \mathrm{O}_{3}$ is shown below using data from the HSC Chemistry database. ${ }^{21)}$

$$
\begin{aligned}
\mathrm{Cd}^{2+}+\mathrm{Na}_{2} \mathrm{~S}_{2} \mathrm{O}_{3} & \Leftrightarrow \mathrm{CdS}_{2} \mathrm{O}_{3}+2 \mathrm{Na}^{+} \\
\Delta \mathrm{G}\left(25^{\circ} \mathrm{C}\right) & =-35.1 \mathrm{~kJ}
\end{aligned}
$$

Another solution that can scrub the loaded $\mathrm{Cd}$ is $\mathrm{NH}_{4} \mathrm{Cl}^{23}{ }^{23}$ Like $\mathrm{Na}_{2} \mathrm{~S}_{2} \mathrm{O}_{3}$, the $\mathrm{Cd}$ scrubbing with $\mathrm{NH}_{4} \mathrm{Cl}$ forms complexes with $\mathrm{NH}_{3}$ or $\mathrm{Cl}^{-}$ions. Since $\mathrm{NH}_{4} \mathrm{Cl}$ can also form complexes of $\mathrm{Zn}$ amine, however, it was not applied to Cd scrubbing in this study. ${ }^{28)}$ When $0.5 \mathrm{M} \mathrm{Na}_{2} \mathrm{~S}_{2} \mathrm{O}_{3}$ was used, only $91 \%$ of the $\mathrm{Cd}$ was scrubbed. The McCabe Thiele diagram for the countercurrent multi-stage scrubbing of $\mathrm{Cd}$ using this concentration of $\mathrm{Na}_{2} \mathrm{~S}_{2} \mathrm{O}_{3}$ was prepared to increase the scrubbing efficiency of $\mathrm{Cd}$ scrubbing by varying the $\mathrm{O} / \mathrm{A}$ ratio, and is shown in Fig. 4. According to the McCabe Thiele diagram, $\mathrm{Cd}$ requires 3 -stage countercurrent scrubbing at operating line 2, i.e., an $\mathrm{O} / \mathrm{A}$ ratio of 2, and 2-stage countercurrent scrubbing at operating line 1, i.e., an $\mathrm{O} / \mathrm{A}$ ratio of 1 . Therefore, multi-stage countercurrent scrubbing was performed under the above two conditions, and the results are shown in Table 6. Even after the multi-stage countercurrent scrubbing experiment, $\mathrm{Zn}$ and $\mathrm{Mn}$ were not scrubbed at all, and only Cd was scrubbed. However, about

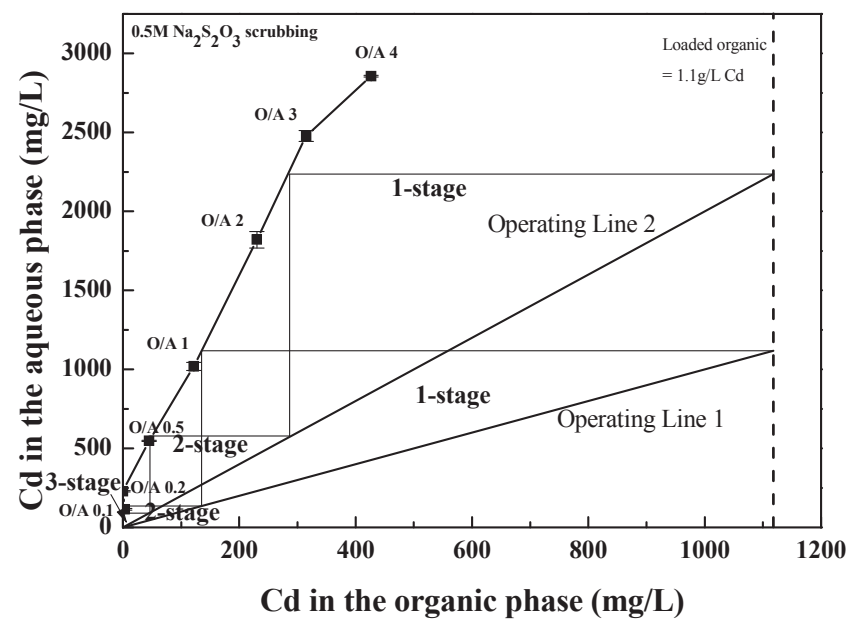

Fig. 4 McCabe Thiele diagram for scrubbing cadmium. 
Table 6 Results of counter-current simulation batch test for $\mathrm{Cd}$ scrubbing.

\begin{tabular}{llll}
\hline $\begin{array}{l}\text { Scrubbing experiment } \\
\text { condition }\end{array}$ & Element & $\begin{array}{l}\text { Scrubbing } \\
\text { solution, mg/L }\end{array}$ & $\begin{array}{l}\text { Scrubbing } \\
\text { efficiency, \% }\end{array}$ \\
\hline 2-stage countercurrent & $\mathrm{Zn}$ & N.D & - \\
scrubbing & $\mathrm{Mn}$ & N.D & - \\
O/A ratio 1 & $\mathrm{Cd}$ & 1082 & 97.5 \\
\hline 3-stage countercurrent & $\mathrm{Zn}$ & N.D & - \\
scrubbing & $\mathrm{Mn}$ & N.D & - \\
O/A ratio 2 & $\mathrm{Cd}$ & 2231 & 100 \\
\hline
\end{tabular}

$2.5 \%$ of the $\mathrm{Cd}$ was not scrubbed using an $\mathrm{O} / \mathrm{A}$ ratio of 1 and 2-stage countercurrent scrubbing; thus, 3-stage countercurrent scrubbing at an $\mathrm{O} / \mathrm{A}$ ratio of 2 was set as the optimum condition. Since $\mathrm{Na}_{2} \mathrm{~S}_{2} \mathrm{O}_{3}$ does not scrub Co at all, it was not used for Co scrubbing. ${ }^{23)}$ Therefore, a separate scrubbing stage with $\mathrm{pH}$-adjusted sulfuric acid is required for scrubbing Co.

\subsection{Zn and Mn stripping procedure and the manufac- ture of zinc manganese sulfate}

The stripping of $\mathrm{Zn}$ and $\mathrm{Mn}$ was carried out using $1.5 \mathrm{M}$ sulfuric acid and setting the $\mathrm{O} / \mathrm{A}$ ratio as high as 6 . The purpose of the high $\mathrm{O} / \mathrm{A}$ ratio is to concentrate $\mathrm{Zn}$ and $\mathrm{Mn}$ into the aqueous phase in order to produce $\mathrm{ZnMnSO}_{4}$ from the final stripping solution. When the $\mathrm{O} / \mathrm{A}$ ratio of the stripping process is increased, however, the concentration of the stripped metal ions increases but the stripping efficiency is decreased. Therefore, in order to increase the stripping efficiency, stripping was carried out using a 2-stage countercurrent stripping procedure. The resulting stripping efficiency for $\mathrm{Zn}$ and $\mathrm{Mn}$ was more than $99 \%$, and both were enriched in the final stripped solution, which contained $27.7 \mathrm{~g} / \mathrm{L}$ of $\mathrm{Zn}$ and $33.6 \mathrm{~g} / \mathrm{L}$ of $\mathrm{Mn}$. The used solvent can be regenerated via a water- and acid-washing process. The mass balance of each element in the solvent extraction, scrubbing, and stripping processes is shown in Fig. 5. Vacuum evaporation was performed using $200 \mathrm{ml}$ of the final stripping solution, and zinc manganese sulfate powder was obtained. The compositional analysis result of this powder and its XRD peaks are shown in Table 7 and Fig. 6, respectively. No other impurities were present, and the powder contained 16.1 mass $\% \mathrm{Mn}$ and 18.4 mass $\% \mathrm{Zn}$. The zinc manganese sulfate XRD peak was not present, but the $\mathrm{ZnSO}_{4} \cdot \mathrm{H}_{2} \mathrm{O}$ peak and the $\mathrm{MnSO}_{4} \cdot \mathrm{H}_{2} \mathrm{O}$ peak overlapped. The purity of the zinc manganese sulfate is $99.9 \%$, which is sufficient for use as a fertilizer for crop cultivation.

\section{Conclusion}

In this study, the simultaneous recovery of $\mathrm{Zn}$ and $\mathrm{Mn}$ from a feed also containing $\mathrm{Cd}, \mathrm{Co}, \mathrm{Ni}$, and $\mathrm{Li}$ was carried

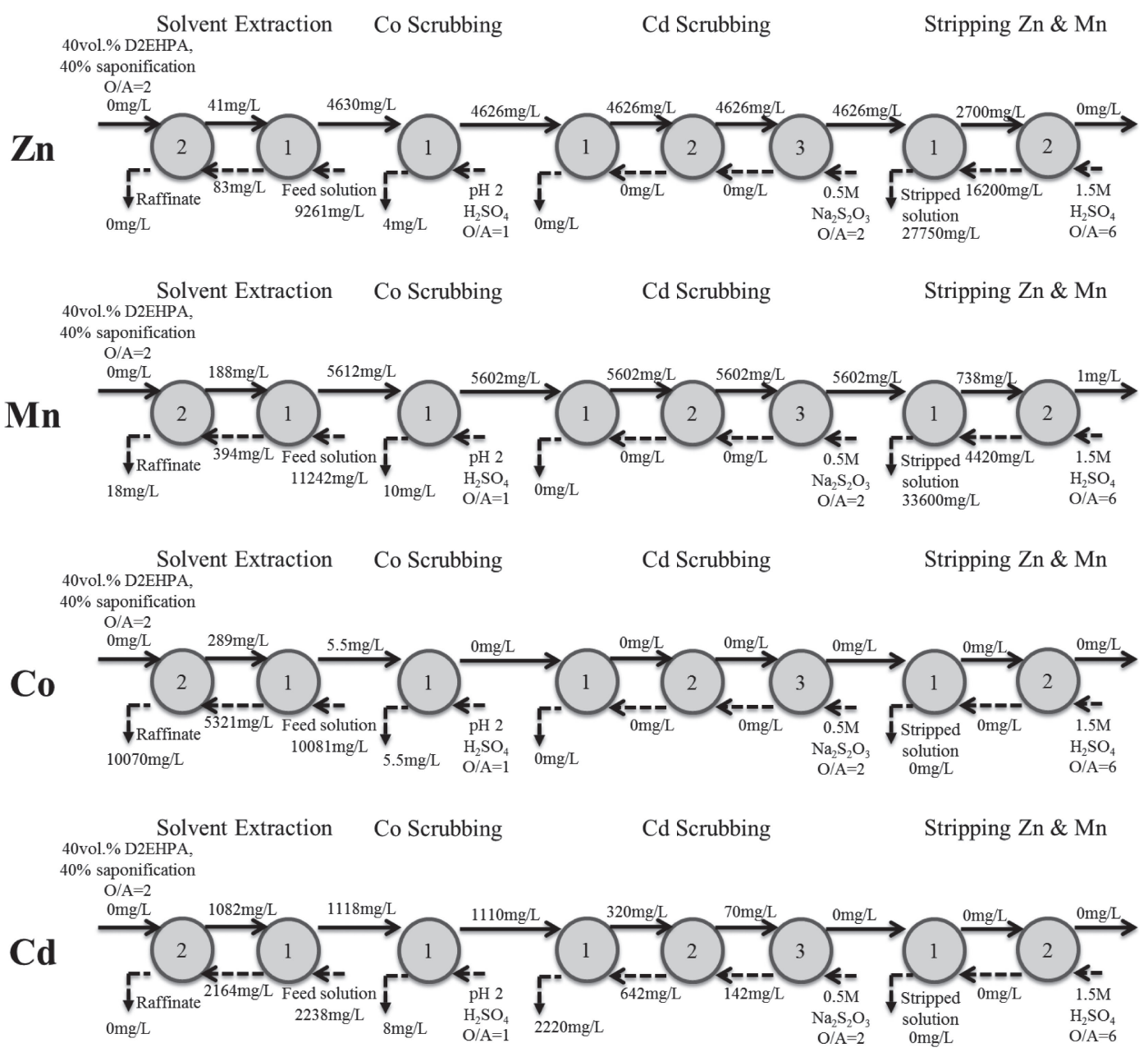

Fig. 5 Mass balance of each element in the hydrometallurgical process. 
Table 7 Elemental composition of zinc manganese sulfate (mass\%).

\begin{tabular}{ll}
\hline Elements of Zinc manganese & \\
sulfate & 18.4 \\
\hline Zn & 16.1 \\
$\mathrm{Mn}$ & N.D \\
$\mathrm{Cd}$ & N.D \\
$\mathrm{Co}$ & N.D \\
$\mathrm{Ni}$ & N.D \\
$\mathrm{Li}$ & N.D \\
$\mathrm{Fe}$ & N.D \\
$\mathrm{Al}$ & N.D \\
$\mathrm{Cu}$ & \\
\hline
\end{tabular}

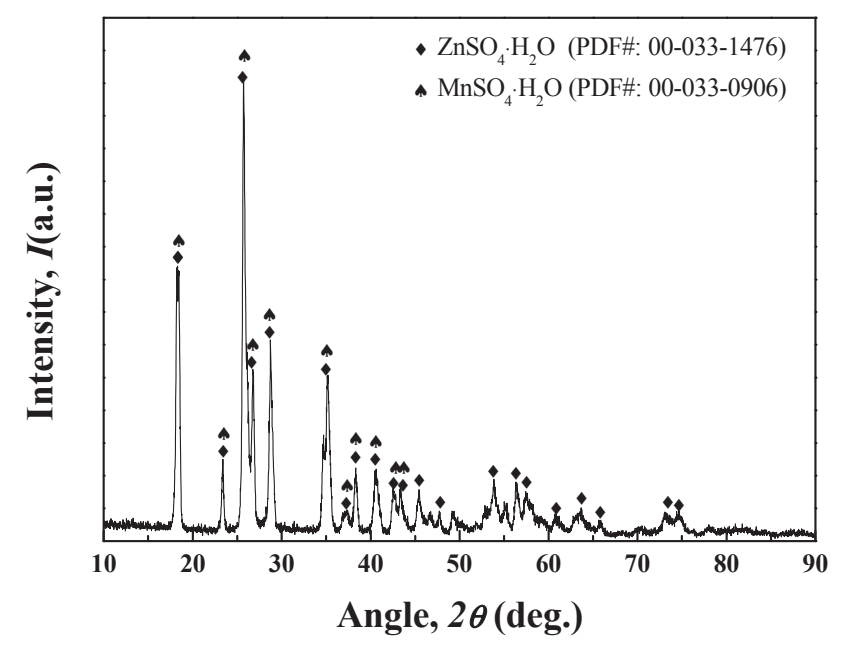

Fig. $6 \mathrm{XRD}$ results of the zinc manganese sulfate.

out through a hydrometallurgical process. The final results of this research are the following:

(1) A feed solution for solvent extraction that contained $\mathrm{Zn}$, $\mathrm{Mn}, \mathrm{Cd}, \mathrm{Co}, \mathrm{Ni}$, and $\mathrm{Li}$ was obtained from various kinds of battery wastes mixed at a certain ratio through stable heat treatment, physical treatment, and a leaching process under the optimum conditions of a previous experiment.

(2) The $\mathrm{pH}$ isotherm experiment showed that it is difficult to separate $\mathrm{Mn}$ and $\mathrm{Cd}$ based on the $\Delta \mathrm{pH}_{50}$ value calculated for the two elements. Therefore, $\mathrm{Zn}, \mathrm{Mn}$, and $\mathrm{Cd}$ were extracted simultaneously. The optimum conditions were 40 vol\% D2EHPA, a 40 vol\% $\mathrm{NaOH}$ concentration, and 2-stage countercurrent extraction at an $\mathrm{O} / \mathrm{A}$ ratio of 1 . Under these conditions, more than 99\% of the $\mathrm{Zn}, \mathrm{Mn}$, and Cd were extracted, and Co was slightly co-extracted as an impurity.

(3) The co-extracted Co was scrubbed using an $\mathrm{O} / \mathrm{A}$ ratio of 1 by sulfuric acid adjusted to $\mathrm{pH} 2$. The loaded organic that had been scrubbed of Co was completely scrubbed of $\mathrm{Cd}$ in a 3-stage countercurrent process using $0.5 \mathrm{M} \mathrm{Na}_{2} \mathrm{~S}_{2} \mathrm{O}_{3}$ at an $\mathrm{O} / \mathrm{A}$ ratio of 2 . There was no loss of $\mathrm{Zn}$ or $\mathrm{Mn}$ during the scrubbing of $\mathrm{Cd}$.
(4) Stripping of $\mathrm{Zn}$ and $\mathrm{Mn}$ was carried out using a 2-stage countercurrent process, an $\mathrm{O} / \mathrm{A}$ ratio of 6 , and $1.5 \mathrm{M}$ sulfuric acid. The $\mathrm{Zn}$ and $\mathrm{Mn}$ were concentrated by the high $\mathrm{O} / \mathrm{A}$ ratio, and finally a $27.7 \mathrm{~g} / \mathrm{L} \mathrm{Zn}$ and a $33.6 \mathrm{~g} / \mathrm{L}$ Mn solution were obtained.

(5) Zinc manganese sulfate powder can be manufactured by vacuum distillation from the highly concentrated $\mathrm{Zn}$ and $\mathrm{Mn}$ sulfate solution. The final product contains 16.1 mass $\% \mathrm{Mn}$ and 18.4 mass $\% \mathrm{Zn}$, and can be utilized as a source of fertilizer.

(6) The remaining elements in the raffinate, such as $\mathrm{Co}, \mathrm{Ni}$, and $\mathrm{Li}$ will be recovered separately. After the recovery of $\mathrm{Zn}, \mathrm{Mn}$, and $\mathrm{Cd}$, the remaining organic will be washed with water and acid and then regenerated to recover metals. The metallurgical process described in this study can be applied to other complex minerals and urban mines having similar compositions.

\section{Acknowledgments}

This study was supported by the R\&D Center for Valuable Recycling (Global-Top R\&D Program) of the Ministry of Environment. (Project No.: 2016002220001)

\section{REFERENCES}

1) Battery Recycling Results in Korea. Korea Battery Recycling Association, http://www.kbra.net/epr/epr5.htm, (accessed 2018-11-24).

2) R. Khan, S. Gul, M. Hamayun and M. Shah: American-Eurasian J. Agri. \& Environ. Sci. 16 (2016) 984-997.

3) M. Hasani, Z. Zamani, G. Savaghebi and R. Fatahi: J. Soil Sci. Plant Nutr. 12 (2012) 471-480.

4) I. De Michelis, F. Ferella, E. Karakaya, F. Beolchini and F. Vegliò: J. Power Sources 172 (2007) 975-983.

5) C.C.B.M. De Souza and J.A.S. Tenorio: J. Power Sources 136 (2004) 191-196.

6) A.L. Salgado, A.M.O. Veloso, D.D. Perira, G.S. Gontijo, A. Salum and M.B. Mansur: J. Power Sources 115 (2003) 367-373.

7) S.M. Shin, J.G. Kang, D.H. Yang, J.S. Sohn and T.H. Kim: Mater. Trans. 48 (2007) 244-248.

8) W.S. Chen, C.T. Liao and K.Y. Lin: Energy Procedia 107 (2017) 167174.

9) J. Zhu, J. Li and Y. Nie: Acta Phys. Chim. Sin. 18 (2002) 536-539.

10) U.J. Umesh and H. Hong: Environ. Technol. 35 (2014) 1263-1268.

11) H. Mahandra, R. Singh and B. Gupta: J. Clean. Prod. 172 (2018) 133142.

12) J. David: J. Power Sources 57 (1995) 71-73.

13) K. Tanong, J. Coudert, G. Mercier and J. Blais: J. Environ. Manage. 181 (2016) 95-107.

14) K. Tanong, L.H. Tran, G. Mercier and J. Blais: J. Clean. Prod. 148 (2017) 233-244.

15) R.A. Kumbasar: Hydrometallurgy 95 (2009) 290-296.

16) B. Gupta, A. Deep and P. Malik: Hydrometallurgy 61 (2001) 65-71.

17) H.K. Haghighi, D. Moradkhani and M.M. Salarirad: Hydrometallurgy 154 (2015) 9-16.

18) M. Daryabor, A. Ahmadi and H. Zilouei: Ultrason. Sonochem. 34 (2017) 931-937.

19) D.J. Shin, S.H. Joo, C.H. Oh, J.P. Wang, J.T. Park, D.J. Min and S.M. Shin: Envrion. Technol. Published online (2018), (cited 2018-11-24).

20) C.Y. Cheng: Hydrometallurgy 56 (2000) 369-386.

21) A. Roine: Sustainable Process Technology and Engineering, (A Manual on HSC Program, Continuous Research \& Development, Finland, 2017).

22) U.S. Environmental Protection Agency: EPA/600/R-07/080, (Office of Research and Development, 2007).

23) C.A. Nogueira, P.C. Oliveira and F.M. Pedrosa: Solvent Extr. Ion Exch. 21 (2003) 717-734. 
24) Science Applications International Corporation: User's Guide UG2052-ENV, (Naval Facilities Engineering Service Center, 2003).

25) T.J. Norberg-King, D.I. Mount, E.J. Durhan, G.T. Ankley and L.P. Burkhard: EPA/600/6-91/003 second ed., (Environmental Research Laboratory, 1999).

26) J.R. Hockett and D.R. Mount: Environ. Toxicol. Chem. 15 (1996)
1687-1693.

27) R.M. Smith and A.E. Martell: Critical Stability Constants, Vol. 4Inorganic Complexes, (Plenum, New York, 1976).

28) I.V. Mishonov, K. Alejski and J. Szymanowski: Solvent Extr. Ion Exch. 22 (2004) 219-241. 